\title{
Transformacja arystokracji rzymskiej na terenach galijskich w V wieku
}

Jak postrzegano, z punktu widzenia arystokracji galorzymskiej, wydarzenia w Imperium sprzed 476 roku? Niejednokrotnie nobilowie oddawali się pod zwierzchnictwo królów barbarzyńskich. Oczywiście, na tej podstawie nie można jednoznacznie stwierdzić, że nie przejęli się klęską Rzymu, bo kto tak naprawdę mógł im zagwarantować utrzymanie dotychczasowych tytułów i stanowisk? Konstantynopol leżał daleko, a miejscowi królowie nie musieli już obawiać się odwetu ze strony Cesarza Wschodu. W zaistniałej sytuacji jedynym logicznym rozwiązaniem było pogodzenie się z zaistniałą sytuacją i wypracowanie optymalnych dla obu stron rozwiązań. Przede wszystkim, jeżeli chodzi o stronę galorzymską, miejscowe elity dążyły do utrzymania tradycyjnej administracji rzymskiej oraz organizacji kościelnych zakorzenionych na tych terenach ${ }^{1}$. Na korzyść arystokracji przemawiało przejmowanie przez nowo powstałe królestwa części rozwiązań organizacyjnych Imperium. Dodatkowo, bardzo wielu barbarzyńskich władców przyjęło chrześcijaństwo w obrządku ariańskim, co niewątpliwie pomagało w pokojowej koegzystencji poszczególnych grup na danym terenie ${ }^{2}$. Dlatego na Zachodzie musiała dokonać się pewnego rodzaju ewolucja, która zaowocowała wytworzeniem nowego porządku, ustanowionego przez trzy ściśle powiązane ze sobą elementy: Romanitas, Germanitas i Christianitas ${ }^{3}$.

1 Większość biskupów galijskich była potomkami znaczących rzymskich nobilów, z kręgów senatorskich. Ponadto, niejednokrotnie duchowni piastowali wysokie stanowiska urzędnicze w Cesarstwie, jak np. Sydoniusz Apollinaris. Zob. D. Zołoteńki, Zachód rzymski w latach 425-476, [w:] Barbarzyńcy u bram imperium, (red.) S. Turlej, Kraków 2007, s. 118-119.

2 Ibidem, s. 119. Czasem przyjęcie chrześcijaństwa w obrządku ariańskim było czynnikiem konfliktogennym, jak np. w państwie Wandalów.

3 Z każdego „systemu” zaczerpnięto pewne elementy, które posłużyły do wytworzenia jednego, spójnego systemu. Z Rzymu zaadaptowano: prawo, administrację i kulturę łacińską, z Barbaricum: novum w stosunkach społecznych i władzy zwierzchniej, a z chrześcijaństwa: synkretyzm religijno-instytucjonalny, ruch monastyczny oraz działalność misyjną. Ibidem, s. 121-122. 
Głównym źródłem, które dostarcza nam informacji na temat dziejów i społeczeństwa galijskiego, są listy zawarte w dziewięciu księgach oraz wiersze ${ }^{4}$, które zachowały się z bogatej twórczości Sydoniusza Apollinarisa. Dzięki tej spuściźnie zachowanej do naszych czasów możemy, do pewnego stopnia, odtworzyć obraz współczesnej autorowi Galii i jej, niejednokrotnie zawiłych, losów na tle przemian zachodzących w całym Cesarstwie Rzymskim. Sydoniusz w swych listach skupia się głównie na południowej części Galii, w której na co dzień mieszkał i sprawował urzędy. W listach i wierszach znaleźć możemy informacje dotyczące rozwoju chrześcijaństwa w Galii, a także idylliczny obraz życia na $w_{s i}{ }^{5}$. Nie oznacza to bynajmniej, że przemilczał on sytuację polityczną, jaka miała miejsce w pozostałych częściach Imperium Zachodniego. Sydoniusz pisze, m.in. w listach do przyjaciół, o niepokojach spowodowanych coraz to śmielszymi poczynaniami ze strony ludów barbarzyńskich, które coraz częściej wdzierały się w granice Cesarstwa, pustosząc ziemie znajdujące się na ich drodze. Jak więc można zauważyć, autor listów w swej korespondencji porusza cały wachlarz tematów dający nam pełen obraz południowej Galii w V wieku.

Co tak naprawdę wiadomo na temat autora owych listów i wierszy? Caius Sollius Modestus Apollinaris Sidonius urodził się ok. 430 roku w Lugdunum nad Rodanem ${ }^{6} \mathrm{w}$ rodzinie arystokratycznej ${ }^{7}$. Tytułami nobilów mogli poszczycić się zarówno pradziad, dziad ${ }^{8}$, jak i ojciec Sydoniusza, którzy sprawowali urzędy prefektów pretorium ${ }^{9}$. O tak wysokiej pozycji społecznej rodziny wspomina autor w swych listach:

(...) ja dla osiągnięcia godności dziedzicznej z nieustannym zabiegam staraniem; ja, którego ojciec, teść, dziadek, pradziadek błyszczeli prefekturami miejskimi i pretoriańskimi, naczelnymi stanowiskami administracyjnymi i wojskowymi! ${ }^{10}$.

Młody Apollinaris otrzymał staranne wykształcenie, które było elementem niezbędnym przy wspinaniu się po drabinie kariery urzędniczej. Był biegły w gramatyce, retoryce i filozofii. Znał piśmiennictwo wybitnych myślicieli takich, jak

4 Wydanie polskie: Sydoniusz Apolinary, Listy $i$ wiersze, przełożył, opracował i wstępami poprzedził M. Brożek, Kraków 2004.

5 Sydoniusz Apolinary, Ep. II 2 (s. 24-28).

6 M. Brożek, Wstęp, [do:] Sydoniusz Apolinary, Listy i wiersze, s. V.

7 O swoim pochodzeniu wspomina Sydoniusz w jednym z listów, przy okazji wygłoszonej przez niego mowy do Bituryngów, na okoliczność wyboru nowego biskupa tego ludu. Podkreśla fakt, że został z osoby świeckiej „,...) przeniesiony do kapłaństwa (...)”. Jednocześnie zostało wyeksponowane jego wysokie urodzenie oraz insygnia piastowanych godności. Zob. Sydoniusz Apolinary, Ep. VII 9 (s. 128).

8 Prawdopodobnie dziad Sydoniusz, również o imieniu Apollinaris, jako pierwszy z rodu przyjął religię chrześcijańską. Zob. J. Styka, Sydoniusz Apollinaris i kultura literacka, Kraków 2008, s. 55.

9 M. Brożek, op. cit., s. VI.

10 Sydoniusz Apolinary, Ep. I 3 (s. 6-7). 
Pitagoras, Platon, Sokrates czy Arystoteles ${ }^{11}$ oraz wielkie dzieła pisarzy, poetów i mówców łacińskich, np. mowy Cycerona ${ }^{12}$. Jako chrześcijanin zapoznawał się również w młodości, ponieważ była to podstawa chrześcijańskiego kształcenia, z Bibliq w wersji Vulgaty Hieronimowej, oraz dziełami pisarzy chrześcijańskich ${ }^{13}$. Sydoniusz, piastując kolejne urzędy, piął się coraz wyżej po szczeblach drabiny urzędniczej. Zajmował stanowisko tribunus et notarius za cesarza Awitusa, a za Majoriana pełnił funkcję cesarskiego komesa ${ }^{14}$. Należy także nadmienić, że w 450 roku Apollinaris poślubił córkę wspomnianego już Flawiusza Eparchiusza Awitusa ${ }^{15}$, byłego praefectus praetorio Galliarum, Papianillę ${ }^{16}$. W międzyczasie, za cesarza Majoriana ${ }^{17}$, wybuchło w Galii powstanie miejscowej arystokracji jako wyraz niezadowolenia z powodu zrzucenia z tronu Awitusa. Konflikt miał zostać zażegnany dzięki interwencji Sydoniusza, który wybłagał u cesarza, by ten oszczędził rodaków Apollinarisa ${ }^{18}$. Następnie, w 468 roku, Sydoniusz objął urząd praefectus urbi ${ }^{19}$ „(...) z łaski [cesarza - przyp. K.G.] Antemiu-

11 O obszernej wiedzy Sydoniusza z zakresu filozofii czy też literatury zarówno greckiej, rzymskiej, jak i chrześcijańskiej świadczy jego znajomość dzieł i twórców m.in. Pitagorasa, Sokratesa, Platona, Hortensjusza, Cezara, Hieronima, Augustyna, czy Ambrożego. Zob. ibidem, IV 3 (s. 60-61).

12 W liście adresowanym do Serranusa, Sydoniusz przytacza fragment jednej z mów Cycerona - o pojęciu szczęścia. Zob. ibidem, II 13 (s. 40-41) i Cicero, Rozmowy tuskulańskie, przekł. J. Śmigaj, Warszawa 2010, s. 191-197.

13 J. Styka, op. cit., s. 55-56. Na doskonałą znajomość Pisma Świętego wskazuje cytowanie przez Sydoniusza fragmentów Ewangelii św. Lukasza, św. Mateusza, Księgi Wyjścia czy też Księgi Psalmów. Zob. Sydoniusz Apolinary, Ep. VI 1 (s. 105) i VII 9 (s. 128-129).

14 D. Zołoteńki, Galia u schyłku panowania rzymskiego, Kraków 2011, s. 32-33.

15 Awitus, w lipcu 455 roku w Arles, został obwołany, po Maksymusie Petroniuszu, cesarzem. Wcześniej piastował urząd magister utriusque militiae, był naczelnikiem wojsk rzymskich oraz osobą znaną ze swego zaangażowania w politykę. Co więcej, kandydatura Awitusa została poparta przez Teodoryka II, ówczesnego króla Wizygotów. Z okazji objęcia przez teścia konsulatu, Sydoniusz wygłosił w Rzymie panegiryk ku czci nowego cesarza, za który został uhonorowany spiżowym posągiem ustawionym na Forum Trajana. Ważnym wspomnienia faktem jest zrzucenie Awitusa z tronu cesarskiego. Po tym wydarzeniu, oszczędzony przez nowego władcę Majoriana, Awitus przymusowo piastował godność biskupią w Placencji nad Padem. Zob. M. Brożek, op. cit., s. VI, J. Styka, op. cit., s. 56; Sydoniusz Apolinary, Oratio. I (s. 195-217).

16 M. Brożek, op. cit., s. VI. W listach Sydoniusz pisze o swym synu Apolinarym oraz o swej córce Roscji. W liście do żony zostały zawarte informacje na temat wychowania córki: „W babci i ciotek ramionach dobrotliwych co rzadko się szczęści wnukom w ich wychowaniu, wychowuje się z powaga; ta jednak nie deformuje jej młodego wieku, lecz kształtuje charakter". Należy także dodać, że jest to jedyny list Sydoniusza do Papianilli w całym woluminie. Zob. Sydoniusz Apolinary, Ep. V 16 (s. 99).

17 Sydoniusz będzie także kilkakrotnie uczestniczył w wyprawach wojennych cesarza Majoriana, m.in. w 460 roku w Hiszpanii. Zob. J. Styka, op. cit., s. 57.

18 Ibidem, s. 56-57.

19 Prefektura Miasta Rzymu była, pod względem stanowiska, tożsama z prefekturą pretorium. 
sza (...)"20. Apollinaris był także członkiem senatu rzymskiego, a od 469/470 lub 471 roku biskupem Arvernorum (Clermont) ${ }^{21}$. Za czasów Sydoniusza miały miejsce bardzo częste zmiany władzy na tronie cesarskim, włącznie z objęciem rządów przez ostatniego z cesarzy zachodniorzymskich Romulusa Augustulusa ${ }^{22}$. Wart podkreślenia jest fakt, iż Sydoniusz, niejednokrotnie utrzymywał przyjacielskie stosunki z władcami barbarzyńskimi, co później zaowocowało jego pośrednictwami, między władcami rzymskimi a np. Wizygotami. Apollinaris, jeszcze za życia swego teścia, nawiązał, właśnie dzięki Awitusowi, znajomości z Wizygotami ${ }^{23}$ zamieszkującymi tereny znajdujące się nad Garumną, Tuluzą ${ }^{24}$. Zatem Sydoniusz, za swojego życia, miał styczność z wieloma imperatorami. O tych kontaktach mogą świadczyć liczne panegiryki pisane ku czci cesarzy: Awitusa, Majoriana czy też Antemiusza ${ }^{25}$.

\section{Arystokracja galorzymska}

W V wieku miały miejsce liczne uzurpacje władzy cesarskiej na Zachodzie. W 411 roku do zdobycia władzy dążył nobil galijski Jowinus, którego lokalna arystokracja, kadra urzędnicza oraz barbarzyńska koalicja (plemiona Burgundów, Alanów, Franków i Alamanów) obwołały, prawdopodobnie w prowincji Germania Prima, cesarzem ${ }^{26}$. Dodatkowo, w tym miejscu należy zgodzić się z Michele Renee Salzman, która wskazuje na czołową rolę arystokracji w Imperium. Stwierdzenie to argumentuje następująco: ,sami cesarze potrzebowali poparcia

Zob. ibidem, s. 56-57. Praefectus urbi był wybierany spośród wysokiej rangi senatorów, pod jego zwierzchnictwem znajdowały się cohortes urbanae. Zob. M. Jaczynowska i M. Pawlak, Starożytny Rzym, Warszawa 2008, s. 451-452.

20 D. Zołoteńki, Zachód rzymski..., s. 32-33.

21 Rozbieżność w datacji może być spowodowana niedokładnym zapisem objęcia przez poszczególne osoby biskupstw. Zob. ibidem, s. 33 i M. Brożek, op. cit., s. VII. Informacja o nadaniu prefektury senatu cesarskiego znajduje się w jednym z listów Sydoniusza. Zob. Sydoniusz Apolinary, Ep. I 9 (s. 17).

22 M. Brożek, op. cit., s. VII. W zasadzie ostatnim cesarzem zachodniorzymskim był, zmarły w 480 roku, Juliusz Nepos, który wszakże po buncie Odoakra nie powrócił do Italii, chociaż ten ostatni uznawał go za legalnego władcę.

23 Kilka listów Sydoniusza adresowanych jest do wywodzącego się z arystokracji Leona, doradcy króla Wizygotów - Euryka. Zob. Sydoniusz Apolinary, Ep. IV 22 (s. 80-81). Co więcej, Sydoniusz pisze o rozciągniętym nad jego twórczością patronacie królowej wizygockiej. Zob. ibidem, IV 8 (s. 66).

${ }^{24}$ M. Brożek, op. cit., s. VI.

25 Sydoniusz Apolinary, op. cit., I 1-3 (carm. IV-VII).

26 M. Pawlak, Konflikty Rzymian z barbarzyńcami nad Renem w latach 365-425, [w:] Barbarzyńcy u bram imperium..., s. 95. 
elit, gdyż dzięki nim mogli utrzymać się u władzy”"27. Można więc stwierdzić, że mamy do czynienia z silnie ugruntowaną pozycją elit.

W tym miejscu właściwe wydaje się scharakteryzowanie elit galorzymskich.

Chrześcijaństwo i kultura łacińska były na Zachodzie, jak powszechnie wiadomo, ściśle ze sobą powiązanie. Nie było mowy o egzystowaniu w środowisku wyższego duchowieństwa bez wcześniejszego uzyskania starannego wykształcenia. Za podstawę przyjmowano zaznajomienie adepta $\mathrm{z}$ twórczością wielkich pisarzy starożytnej Grecji, począwszy od Homera, analizując, według obowiązującego wzorca ${ }^{28}$, zarówno teksty czerpiące garściami z mitologii pogańskiej, jak również wielkie mowy opisujące dawne wydarzenia. Następnie płynnie przechodzono przez poszczególne gatunki literackie, by w końcu opanować spuściznę rzymskich mistrzów słowa ${ }^{29}$. Wykształcony człowiek powinien być biegły w tej materii, zarówno jeśli chodzi o sztukę, jak i literaturę. Cała ówczesna retoryka opierała się na dorobku minionych pokoleń, a dzięki doskonałemu jej opanowaniu możliwy był awans społeczny. Ponadto, dzięki licznym kopiom Pisma Świętego, mamy do czynienia z rozpropagowaniem wśród różnych warstw społecznych, literatury chrześcijańskiej. Zapotrzebowanie to zaowocowało wytworzeniem nowego gatunku literackiego, jakim były, pisane w różnych językach (m.in. grece, łacinie, języku syryjskim czy też koptyjskim), żywoty świętych, zbiory dotyczące cudów, czy akta męczenników ${ }^{30}$.

$\mathrm{Na}$ bardzo ważną rolę wykształcenia w Cesarstwie wskazuje w swych listach, adresowanych do galorzymskiej arystokracji, Sydoniusz Apollinaris. Pisze on o wyższości ludzi zdobywających wykształcenie: „(...) jak bardzo wykształceni wyprzedzają niewykształconych, jak ludzie zwierzęta"31. Jednocześnie autor listów boleje nad upadkiem łaciny na terenach zamieszkałych przez plemiona barbarzyńskie, swe niepokoje wyraża w następujących słowach: „Tak to wspa-

27 Jak podaje M. R. Salzman: „They needed to gain the legitimating support of the aristocracy, a class in possession of significant resources and prestige as well as expertise of the sort needed to maintain the imperial bureaucracy". Na tej podstawie zbyt daleko idącym wnioskiem nie powinno wydawać się stwierdzenie, że elity, a przede wszystkim poparcie z ich strony, stanowiły kluczowy element ówczesnej polityki, a także podstawę administracyjną prawidłowego funkcjonowania Cesarstwa na Zachodzie. Zob. M. R. Salzman, The Making of a Christian Aristocracy. Social and religious change in the Western Roman Empire, Harvard 2004, s. 179.

28 Wytyczne do analizy tekstów kultury antycznej wydał, u schyłku IV wieku, Bazyli z Cezarei w instrukcji pt. „Do młodzieńców, o pożytku z czytania pism pogańskich”. Zob. E. Szabat, Edukacja i kultura $w V$ wieku, [w:] Świat rzymski $w V$ wieku, (red.) R. Kosiński i K. Twardowska, Kraków 2010, s. 423.

29 Ibidem, s. 423.

30 Znakomity przykład dzieła, dostępnego na szeroką skalę, stanowi Żywot św. Antoniego autorstwa św. Atanazego. Natomiast do wiernych niepiśmiennych przekaz niesiony przez Kościół docierał za pośrednictwem sztuki: malowidła, rzeźba czy różnego rodzaju elementy architektoniczne o tematyce sakralnej. Zob. ibidem, s. 424.

31 Sydoniusz Apolinary, Ep. IV 17 (s. 75). 
niałość mowy rzymskiej, jeśli jakaś gdziekolwiek jeszcze trwa, dawno już na belgijskich i nadreńskich ziemiach zniweczona (...)"32. Sydoniusz wyraża nie tylko ubolewanie z powodu zaniku kultury, ale również wskazuje ubytki terytorialne Imperium.

Powróćmy jednak do kwestii związanych z edukacją. W pismach Apollinarisa zawarte są informacje wskazujące na stosunek nobilów do wykształcenia. Po pierwsze, zbiory pism wielkich twórców, zarówno pogańskich, jak i Ojców Kościoła uważano za prawdziwy skarb: „Trojaką błyszczał ten mistrz biblioteką, rzymską i grecką oraz chrześcijańską"33. Dlatego każdy szanujący się arystokrata powinien robić, co następuje:

(...) musisz bez niedbałości czytywać bez końca się rozczytywać. I nie pozwolić, by cię od tego zadania odrywała żona, lada dzień mająca być wprowadzona do twego domu. Musisz dobrze pamiętać, jak to niegdyś Marcja Hortensjuszowi, Terencja Tulliuszowi, Kalpurnia Pliniuszowi (...) trzymały świece i kandelabry przy czytaniu i rozmyślaniu (...) jeśli ci chce się skarżyć, że przez współpracę kobiecą, poza prozą, twój talent poetycki i gładkość twego języka osełkami ciągłych studiów szlifowana, doznaje znarowienia - przypomnij sobie, że Korynna często Owidiuszowi dopełniała wiersza, Lesbia współpracowała z Katullusem (...) Stąd jasno widać, że ochotnym małżeństwo daje sposobność do studiów, a leniwym okazję do wymówki. A zatem przyłóż się do pracy i niech też tłum nieuków nie odbiera ci poczucia wartości, skoro natura tak sprawia, że we wszystkich sztukach tym cenniejszy jest triumf umiejętności im rzadszy ${ }^{34}$.

Jednocześnie Apollinaris wskazuje na cechy dobrej żony, mającej być wsparciem i towarzyszką dla swego męża. Dodatkową zachętą do rozwoju piśmiennictwa, podkreślaną przez Sydoniusza, miała być nagroda za najlepsze dzieło: „,...) utwór to godny, by go uwiecznić na tablicy złotymi gwoźdźmi przybitej na mównicy publicznej albo na Kapitolu" ${ }^{35}$. Tego rodzaju wyróżnienie wiązało się z bardzo dużym prestiżem, jaki mógł zyskać doceniony przez władzę twórca.

Jednak mimo tak licznych korzyści, zarówno intelektualnych, jak i prestiżowych, nie można było powstrzymać nasilającego się załamania kultury łacińskiej. W liście do Jana, galijskiego gramatyka, takimi słowami wyraża Apollinaris pobożne życzenie na przetrwanie ciężkich czasów: „W tobie jednym, nauczycielu,

\footnotetext{
32 Co ciekawsze, Apollinaris swoje niepokoje na temat upadku kultury łacińskiej wyraża w liście adresowanym do Arbogasta, zaprzyjaźnionego barbarzyńcy wywodzącego się z Trewerów osiadłych nad Mozelą. Jednocześnie autor wskazuje na dobrą znajomość łaciny przez plemiona barbarzyńskie: „(...) wspaniałość mowy rzymskiej (...) w tobie się ostała, u którego, czy zaczynasz mówić, czy kończysz, słowa nawet nie kuleją, choć prawa łacińskie u granicy upadły”. Zob. Sydoniusz Apolinary, Ep. IV 17 (s. 75).

33 Ibidem, IV 11 (s. 69).

34 Ibidem, II 10 (s. 37).

35 Ibidem, I 11 (s. 19).
} 
w tych burzliwych czasach wojen łacińska mowa w Galii znalazła port, podczas gdy broń doznała rozbicia" ${ }^{36}$, gdyż

(...) ci mianowicie, co u ciebie, mistrzu, kształcąc się i wychowując wśród niepokonanego, przecież jednak obcego ludu, chorągwie czasów dawniejszych ocalą. Bo gdy już znikną stopnie godności, przez które zwykło się odróżniać każdego od najniższego do najwyższego, jedynym kryterium szlachetności pozostanie wykształcenie w piśmiennictwie (...). Bo i myśmy się nauczyli pisać i wypracowywać coś, co by przeszłość mogła czytać, i z twej przynajmniej szkoły, z twego nauczania wyrośnie nam odpowiedni zastęp czytelników ${ }^{37}$.

W innym liście Sydoniusz podkreśla, jak ważna jest rola edukacji w rozwoju młodego człowieka, jednocześnie wyraża ubolewanie nad opuszczeniem w nauce swego syna ${ }^{38}$.

Sydoniusz, nie pozostając bierny, sam wcielił się w rolę nauczyciela, przekazuje wskazówki odnośnie tego, jak powinno się poprawnie pisać:

W treści kontrowersyjnej dzielny i muskularny. W satyrycznej staranny i gryzący. W tragicznej srogi i płaczliwy. W komediowej dowcipny i różnorodny. W weselnej młody w słowach, w życzeniach gorący. W bukolicznej czujny, oszczędny, śpiewny. W wiejskiej tak bardzo wiejski, że wcale nie wsiowy ${ }^{39}$.

Wspomina także, tymi oto słowami, o poetach galijskich: „Piękne Ataksu nucą łabędzie" 40 . Jednak wzmiankuje, o tym, że i oni przemijają, a mało kto dba już o poprawność języka ${ }^{41}$. Zdawać by się mogło, że w tych czasach tylko demagogia ma jeszcze posłuch: „Tak ten demagog ludowy, jak chciał, tak i porwał płochego tłumu podatność. Był bowiem Peoniusz w pełni człowiekiem plebsu. Często on trybuńskim wichrzeniem wzburzał morze buntów"42. Uwidacznia się tu także rozdźwięk między pospólstwem a nobilami, mającymi reprezentować wykształconą, i przez to wyższą, warstwę społeczną, co jest bardziej widoczne w następujących frazach: „(...) gdyby nie wy, choć nieliczni, przestrzegający właściwej językowi łacińskiemu czystości przed rdzą trywialnych barbaryzmów, język ten w krótkim czasie do cna zepsuty byśmy opłakiwali. Tak wszelka nobilnej mowy purpura zblaknie przez niedbalstwo pospólstwa" ${ }^{43}$. Niejako podsumowując rozważania

\footnotetext{
36 Ibidem, VIII 2 (s. 141).

37 Ibidem, VIII 2 (s. 141).

38 Ibidem, IX 1 (s. 165).

39 Ibidem, VIII 11 (s. 157).

40 Ibidem, IX 15 (s. 188).

41 Ibidem, IX 7 (s. 170-171).

42 Ibidem, I 11 (s. 19).

43 Ibidem, II 10 (s. 35).
} 
na temat wykształcenia autor tak oto pisze: „(...) niewielu dziś studia szanuje. A przy tym z natury w sercach ludzkich utrwaliła się i zakorzeniła wada, że kto nie zna nauk, nie podziwia ich znawców" ${ }^{4}$. W taki oto sposób uwidoczniona została ogromna rola wykształcenia, zwłaszcza w kręgach arystokratycznych.

Elity królestw barbarzyńskich także, z biegiem czasu, zaczęły doceniać dorobek piśmienniczy Imperium. Niewątpliwy, pozytywny wpływ na to miała ówczesna sytuacja królestw. Wraz z utrwaleniem swej władzy na podbitych terenach oraz rozwojem gospodarczym posiadanych ziem, następowało ożywienie w sferze intelektualnej. Coraz częściej nowa władza, czerpiąc wzorce płynące z Cesarstwa, otaczała się poetami łacińskimi, którzy stawali się nadwornymi pisarzami oraz wychowawcami synów nowych królów. W Barbaricum powoli rozpowszechniała się moda na twórczość panegiryczną. Władcy zamawiali utwory opiewające ich czyny, a także zezwalali na powstawanie szkół, mających kształcić przyszłych bardów ${ }^{45}$.

Rozkwit kulturalny wśród barbarzyńców znajduje swoje odzwierciedlenie w twórczości Sydoniusza, który przychylniej zaczął odnosić się do Wizygotów. Apollinaris, w jednym ze swych listów, zachwalał coraz to lepsze umiejętności w posługiwaniu się łaciną wśród wyższych warstw społecznych Barbaricum. Wspomnieć należy, iż Galia pod względem rozwoju kultury łacińskiej nie była jednolita. O ile południowa jej część sprzyjała rozkwitowi intelektualnemu, o tyle północ charakteryzowała się jej załamaniem. Nobilowie niejednokrotnie przechodzili na stronę królów barbarzyńskich, stając się częścią nowej administracji. Dzięki tym kontaktom możliwe było krzewienie edukacji na zarządzanych przez notabli galorzymskich terenach. Ponadto, w tym czasie za jeden z najważniejszych ośrodków intelektualnych uznawano, utworzony przez arystokrację i elity intelektualne z Galii, klasztor na wyspie Lerinum (Lerins), z którego wywodziło się wielu biskupów ${ }^{46}$. Dzięki takim ośrodkom możliwe było trwanie kultury łacińskiej i zachowanie tożsamości obywateli Wiecznego Miasta. Co więcej, dbający

44 Ibidem, V 10 (s. 95).

45 Na terenie północnej Afryki, będącej pod zwierzchnictwem Wandalów, powstawały, m.in. za panowania Guntamunda (484-496) i Trasamunda (493-523), szkoły w Kartaginie. W tym czasie nastąpił rozwój poezji, wydano zbiór poematów łacińskich pt. Anthologia Latina, utwory De Laudibus Dei autorstwa Drakoncjusza. Zob. E. Szabat, op. cit., s. 428-429.

46 Założycielem tej monastycznej wspólnoty był Honorat z Arelate (Arles). Z tejże wspólnoty wywodzili się m.in. tacy twórcy, jak: Hilary z Arelate, Lupus z Tricasses (Troyes), Eucheriusz z Lugdunum (Lyon) czy Salwian z Massili (Marseille), autor De gunbernatione Dei. Dzieło to miało służyć wyjaśnieniu zesłanej przez Boga kary - w postaci nieszczęść tego świata - zarówno na Rzym, jak i wszystkich chrześcijan, którzy dopuścili się grzechu, wiodąc występne i niemoralne życie. Autor podkreślał zepsucie dotychczasowych elit Imperium oraz wyzysk bezbronnych i biednych, panujący za dawnych czasów. Posługując się przykładami zaczerpniętymi ze współczesnych mu wydarzeń, przedstawiał dobre państwa, czyli królestwa barbarzyńskie, których fundamentem funkcjonowania miały być prawa dbające o człowieka, niezależnie od pochodzenia społecznego. Zob. ibidem, s. 429-430. 
o spuściznę literacką przodków, arystokraci utrzymywali w swych dobrach wspaniałe biblioteki wypełnione po brzegi dziełami wielkich twórców. Przykład tak posażnej biblioteczki przywołuje Sydoniusz:

Ówdzie do dyspozycji było pełno woluminów. Tu masz wrażenie, że widzisz półki biblioteczne, że kliny Ateneum, czy regały księgarza (...) tak się czytało takich autorów, jak Augustyn i Warron, Horacy i Prudencjusz, autorzy podobnego pisarstwa. Między innymi pilnie czytany był przez wyznawców naszej wiary Orygenes Stalowy w tłumaczeniu Tyraniusza Rufina ${ }^{47}$,

a czas wolny, ludzie uczeni, spędzali na dysputach. Wart podkreślenia jest także fakt, iż zarówno mężczyźni, jak i kobiety mieli dostęp do dzieł, chociaż zróżnicowanych pod względem treści: „(...) w księgach przy miejscach dla kobiet były treści religijne, a przy tych dla mężczyzn woluminy nobilitowane łacińską wymownością (...)" "48. Uwadze umknąć nie zdoła, że, w ujęciu Apollinarisa, dla niewiast odpowiedniejsze były dzieła o tematyce chrześcijańskiej. Na uwagę zasługuje stwierdzenie M. R. Salzman, w myśl którego kobiety wywodzące się $\mathrm{z}$ arystokracji były obdarzone takimi samymi cnotami (virtutis) jak mężczyźni ${ }^{49}$. Podobnie na temat zacnych i szanowanych kobiet wypowiada się w swych listach Sydoniusz. Jednocześnie podkreślona została rola matron, uczestniczących zarówno w życiu religijnym, jak i pełniących rolę mecenasów ${ }^{50}$. W przypadku kobiet akcentowano takie cnoty, jak: niewinność, skromność, wierność, posłuszeństwo wobec rodziców i męża ${ }^{51}$.

Przede wszystkim urodzenie oraz piastowany urząd wskazywał na pochodzenie społeczne. Jednocześnie, niejako w myśl zasady noblesse oblige, arystokrata powinien odznaczać się pewnymi przymiotami stawiającymi go, według Apollinarisa, wyżej w hierarchii społecznej. Z racji tego Sydoniusz przekazuje młodym nobilom wskazówki, mające pomóc w osiągnięciu wysokiego stanowiska. Aby podjąć służbę w cesarskich szeregach należy mieć „,...) odpowiedni wiek i pełnię sił ciała i ducha" 52 , ponadto być posażnym w pieniądze na ewentualne wydatki związane ze stanowiskiem, inwentarz - przede wszystkim konie - oraz bogate stroje $^{53}$. Wielu badaczy wykazuje, iż wyznacznikami statusu w społeczeństwie

47 Sydoniusz Apolinary, Ep. II 9 (s. 33).

48 Ibidem, II 9 (s. 33).

49 M. R. Salzman, op. cit., s. 56. Już na przełomie II/III wieku pisarze chrześcijańscy, m.in. Klemens Aleksandryjski, twierdzili, iż cnota jest taka sama zarówno w przypadku kobiet, jak i mężczyzn.

50 Ibidem, s. 56-57.

51 Ibidem, s. 60.

52 Sydoniusz Apolinary, Ep. I 6 (s. 11).

53 Ibidem, I 6 (s. 11). Elementy garderoby były wyznacznikiem statusu społecznego. Sydoniusz, wspominając cesarskie zaślubiny, nie omieszkał pominąć wzmianki na temat ubioru: „Panna 
rzymskim były pewne elementy z życia codziennego, podkreślające przynależność do danego stanu. W przypadku arystokracji można mówić o następujących komponentach zarezerwowanych dla tej właśnie grupy. Najbardziej widocznym wyróżnikiem statusu był oczywiście ubiór, kolejnymi: otaczanie się odpowiednimi osobami, zarówno konotacje z rodzinami senatorskimi, jak i odpowiednia klientela, oraz posiadanie zasobów materialnych. Jednocześnie, jeżeli mówimy o sprawach finansowych, wart podkreślenia jest aspekt posiadania wiejskich włości ${ }^{54}$, których szczegółowe opisy można odnaleźć w listach Apollinarisa. Zarówno wielkość, jak i wyposażenie willi były wyznacznikiem wysokiej pozycji społecznej. O zamożności świadczyły bogato zdobione wnętrza, pełne różnego rodzaju sprzętów ${ }^{55}$. Właścicieli tychże włości określano mianem senatores ${ }^{56}$. Zapewne dlatego, iż większość z nich wchodziła w skład senatu. Należy dodać, iż dla V wieku, opierając się na zapiskach Olympiodorusa, M. R. Salzman podaje, że roczny dochód najbogatszych rodzin wynosił ok. 4 tys. funtów złota otrzymywanych z najmu. Oczywiście, były to wartości zmienne. Jako przykład wzrostu tejże kwoty możemy podać, dodając do funduszy czerpanych z najmu, m.in. środki ze sprzedaży zboża czy też wina, które miały sięgać aż $1 / 3$ złota płynącego z najmu ${ }^{57}$. Ziemia dostarczała ogromnych korzyści majątkowych.

Kolejny element charakterystyczny dla elit łączył sprawy o naturze, określmy je mianem, duchowych, jak i materialnych. Arystokracja cieszyła się powszechnym prestiżem (gloria) wśród lokalnych społeczności. Miało to związek m.in. ze wspomnianym już aspektem finansowym. Swego rodzaju płynność finansowa wpływała korzystnie na rozwój mecenatu. Elity, w oczach społeczeństwa, postrzegano jako restauratorów i fundatorów licznych budowli, patronów igrzysk czy też lokalnych doradców prawnych, a także obrońców ${ }^{58}$. Patronat był elementem pozwalającym wspiąć się na wyżyny hierarchii społecznej. To właśnie dzięki

wprawdzie już wydana, narzeczony odłożył wieniec, konsular zdobną tunikę, druhna suknię, ten zaszczycony togę, ten pozbawiony sławy opończę (...)". Wskazane tym samym zostały elementy ubioru charakterystyczne dla danej klasy społecznej. Zob. ibidem, I 5 (s. 10).

54 M. R. Salzman, op. cit., s. 19-20.

55 Ibidem, s. 46.

56 Dla VI wieku tytuł senator był formą na określenie osoby wywodzącej się ze starego rodu wielkich właścicieli ziemskich. Zob. A. E. Jones, Social mobility in late antique Gaul. Strategies and opportunities for the non-elite, Cambridge 2009, s. 82.

57 Dodatkowym aspektem wpływającym na podwyższenie dochodów miały być: zwiększenie stanu posiadania na drodze zawarcia małżeństwa, dziedziczenie własności, zakup ziem bądź też polityczne działania. Być może, jeżeli chodzi o ostatni aspekt, miało to związek z narzucaniem określonych cen produktów przez wielkich posiadaczy kontrolujących rynki. Zob. M. R. Salzman, op. cit., s. 25-26.

58 Podobna rzecz miała miejsce ze sferą religijną. Elity miały dbać o finansowanie budowy obiektów sakralnych, jak również składanie pieniężnych ofiar na kościół czy też organizowanie uroczystości religijnych. Dodatkowo elity pełniły funkcję reprezentantów swych miast podczas wielkich świąt wyprawianych przez władze centralne. Zob. ibidem, s. 26 i 29. 
niemu wytworzył się pewien specyficzny model łączący w sobie trzy aspekty: hierarchię, zmienność i różnorodnośćc5.

Wróćmy jednak do Sydoniusza pouczającego młodzieńców. Według powszechnych zwyczajów młody nobil powinien także podróżować, poznawać świat, zamiast ograniczać się jedynie do pobytu we własnych dobrach ${ }^{60}$, gdyż: „(...) wstyd ci, jeślibyś miał pozostać między poganiaczami wołów i pasterzami chrumkających świń!” ${ }^{1}$. Idealnym zestawieniem wydaje się być: „Splendor (...) familii, szlachetność obyczajów, odziedziczona po ojcach majętność, młodzieńczy zapał do wszelkiej zaszczytnej działalności (...)"'62. Dla przykładu przywołany zostaje awans, do godności patrycjuszowskiej, Ekdycjusza ${ }^{63}$, który „,...) chęć do osiągnięcia godności wyraził (...) w szyku bojowym, i skarb publiczny wzbogacił nie jako ktoś prywatny pieniądzem, lecz wojennymi łupami" ${ }^{4}$. Oczywiście, awans społeczny można było zapewnić sobie poprzez zgromadzenie odpowiedniego majątku oraz sięgnięcie po wysokie urzędy i tym samym wybicie się z niższych kręgów. Jak wskazuje Allen E. Jones, dość popularnym aktem podkreślającym zamożność było np. zostanie fundatorem kościoła ${ }^{65}$. Jeżeli zaś chodzi o wysokie urzędy, wręcz pożądana była przynależność do struktur cesarskich bądź też kościelnych. Dzięki zdobytemu doświadczeniu można było szybciej wspinać się po szczeblach kariery urzędniczej. Dodatkowo, bardzo korzystne było uzyskanie listów polecających i zawieranie przyjaźni. Sydoniusz sam, w liście do Petroniusza, poleca swego powinowatego, diakona Windycjusza $^{66}$. Pisanie listów polecających było powszechnie stosowaną praktyką. Dodatkowo, dzięki oddawaniu przysług i wymianie listów klienci pomnażali prestiż

\footnotetext{
59 Patronat miał stanowić fundament, przekazywany z pokolenia na pokolenie, na którym opierało się społeczeństwo. W wyniku formowania się królestw barbarzyńskich nowymi patronami stawali się władcy Barbaricum i to właśnie w ich kręgu kontynuowano tradycję mecenatu. Zob. A. E. Jones, op. cit., s. 75 i $88-89$.

60 Sydoniusz nakazuje „Przestań tyle zajmować się wsią ku obrazie nobilności. Jeśli pole w miarę uprawiasz, posiadasz je. Jeśli za dużo, sam stajesz się jego własnością". Zob. Sydoniusz Apolinary, Ep. VIII 8 (s. 149).

61 W liście do przyjaciela, poety Hereniusza, Sydoniusz opisuje swą podróż z Lugdunum do Wiecznego Miasta, gdzie, w 468 roku, został praefectus urbi. To właśnie Rzym jest miejscem, które każdy młody człowiek rozpoczynający karierę powinien zwiedzić, przynajmniej raz zobaczyć „(...) siedzibę praw, matkę nauk, kurię godności, głowę świata, ojczyznę wolności, w którym to mieście jedynym na całym świecie sami tylko barbarzyńcy i niewolnicy są ludźmi bez obywatelstwa (...)". Zob. ibidem, I 5 (s. 8-10) i I 6 (s. 11).

62 Ibidem, II 4 (s. 29).

63 Egdycjusz był bratem żony Sydoniusza Apollinarisa. Zob. ibidem, II 1 (s. 23-24), III 3 (s. 44-46) i V 16 (s. 98-99).

64 Ibidem, V 16 (s. 98).

65 A. E. Jones, op. cit., s. 76.

66 Sydoniusz Apolinary, Ep. V 1 (s. 86).
} 
wielkich panów i zabezpieczali swoje miejsce w środowisku arystokratycznym ${ }^{67}$. Dlatego tak ważne jest, aby młodzi zjednywali sobie przychylność osób w różnym wieku: „Starszych (...) usłużnością, rówieśników pomocą”68. Jak widzimy, bardzo ważnym elementem spajającym kręgi arystokratyczne była przyjaźń (amicitia), wzmacniana dodatkowo przez lojalność i rzetelność. Podtrzymywanie jej było ściśle związane z korespondencją ${ }^{69}$. Listy stawały się niewątpliwie rzeczywistym exemplum amicitiae.

Jednak mimo tak wielkiej zażyłości, wśród arystokratów znajdowały się osoby sprzeniewierzające się zakorzenionym tradycjom i praktykom obowiązującym w kręgu elit. Sydoniusz przywołuje, ku przestrodze, sylwetkę Arwanda, praefectus praetorio Galliarum, piastującego ten urząd przez pięć lat ${ }^{70}$. Jego rządy miało cechować lekceważenie innych urzędników, ogromne zadłużenie, niesłuchanie rad, wyśmiewanie wszystkich, podejrzliwość oraz ciągła irytacja ${ }^{71}$. Te wszystkie przywary były, według Apollinarisa, niegodne nobila, prowadziły do zguby ${ }^{72}$. Sydoniusz odnotowuje także inną postać postępującą wbrew normom zarezerwowanym dla arystokracji - Seronatusa - określanego mianem bestii, tyrana i ciemiężyciela Arwernii, który nie okazywał litości, poniżał bezbronnych, był okrutnym i niesprawiedliwym sędzią ${ }^{73}$. Na szczególną uwagę zasługuje nastę-

67 M. R. Salzman, op. cit., s. 54.

68 Sydoniusz Apolinary, Ep. VII 2 (s. 117).

${ }^{69}$ M. R. Salzman, op. cit., s. 54. Również dla Sydoniusza bardzo ważne było podtrzymywanie przyjaźni, jak to możemy wnioskować ze słów: „I niczego nie wypada nam tak się wystrzegać jak tego, by przez nas przypadkiem miała się przedawnić przyjaźn naszych ojców i dziadków”. Zob. Sydoniusz Apolinary, Ep. V 9 (s. 93).

70 Arward piastował wspominany urząd przez dwie kadencje. Według Sydoniusza, pierwsza kadencja cechowała się aprobatą i przysporzyła prefektowi popularności, a druga przyniosła spustoszenie, co skutkowało niezadowoleniem ze strony miejscowej arystokracji. Zob. ibidem, I 7 (s. 12-15).

71 Ibidem, I 7 (s. 12).

72 Niezadowolenie z rządów Arwanda było tak silne, iż zdecydowano wysłać poselstwo z Galii i wnieść przeciw prefektowi publiczne oskarżenie. Arwand został aresztowany i odesłany do Rzymu, gdzie stanął przed sądem. W wyniku procesu, udowodniono mu zdradę stanu, a zatem obrazę cesarskiego majestatu, co skutkowało pozbawieniem wszystkich godności, tytułów i przywilejów. Co więcej „....) przez sąd w drugim terminie (...) skazany na śmierć, rzucony został na wyspę węża Epidaura, gdzie oszpecony aż do boleści nieprzyjaciół i od spraw ludzkich odsunięty, jakby wypluty z gardła wymiotującej Fortuny, ciągnął teraz swe życie - na podstawie starej uchwały senatu z czasów Tyberiusza - jeszcze trzydzieści dni, w strachu przed hakiem, gemońskimi schodami i stryczkiem godzinami niepokojącego go oprawcy". Zob. ibidem, I 7 (s. 15).

73 Według Sydoniusza - Seronatus był szaleńcem, a jego rządy charakteryzowały się odwróceniem porządku: „Wszystko czego pożąda, niby chce kupić. Ale nie płaci i gardzi towarem, nie biorąc go i rezygnując z niego. Na zebraniu rozkazuje, w radzie milczy. W kościele żartuje, przy uczcie mówi kazania. W mieszkaniu skazuje, w sądzie w czasie rozpraw drzemie. Codziennie zapełnia las uchodźcami, a miasta wrogami; ołtarze winnymi, a więzienia duchownymi. Raduje się Gotami, na Rzymian nastaje". Zob. ibidem, II 1 (s. 23-24) i V 13 (s. 96-97). 
pujący zapis ,„SSeronatus - przyp. K.G.] Raduje się Gotami, na Rzymian nastaje. Naigrawa się z prefektów, igra z rachmistrzami. Prawa Teodozjusza depcze, a głosząc ustawy Teodoryka docieka starych przekroczeń, a nowych podatków (...). Jeśli ze strony państwa nie ma żadnej pomocy, żadnej obrony, jeśli Antemiusz nie ma, jak mówią, żadnych sił, to nobilowie postanawiają za twym [patrycjusza Ekdycjusza - przyp. K.G.] przewodem opuścić ojczyznę, albo zapuścić włosy" 74 . W tym passusie ukazana została nie tylko sylwetka osoby zachowującej się niegodnie, ale przede wszystkim została podkreślona słabość Imperium, wynikająca z niedostatku wojska. Tak, więc arystokraci, m.in. galorzymscy, oddawali się pod zwierzchnictwo królów barbarzyńskich, o czym ma świadczyć próba wdrażania przez Seronatusa praw Teodoryka. Podsumowując powyższe rozważania, należy przyznać rację A. E. Jonesowi, który tak oto charakteryzuje arystokrację: ,(...) the principal attributes for nobility to be birth, high office, wealth, property, social affiliation, »good character «, and a classical education"75. Te same elementy wskazuje M. R. Salzman, opisując idealny model „lepszej części rodzaju ludzkiego”, jak określił elity mówca Symachus ${ }^{76}$. Wszystkie te elementy były spoiwem łączącym rzymskich nobilów. Być może najistotniejszym atrybutem tożsamości elit była przynależność do Imperium. To dzięki niej identyfikowano poszczególnych członków zbiorowości, w jej granicach dokonywano podziałów społeczeństwa na stany. Osłabienie armii rzymskiej na terenach galijskich pociągało za sobą straty terytorialne, od 418 roku, na rzecz plemion barbarzyńskich. Stąd konieczność poszukiwania alternatywy, mającej zapewnić w miarę stabilną sytuację w Galii. W wyniku tego niezbędne stało się wsparcie Cesarstwa Wschodniego, jednak ono również borykało się z wewnętrznymi problemami, dlatego Zachód nie mógł liczyć na zbyt dużą pomoc ${ }^{77}$.

Jak widzimy, w czasach niepokoju nobilowie mieli następujący dylemat: albo opuszczą swoje dobra i wyjadą, być może do Rzymu, albo pogodzą się z nową rzeczywistością i staną się częścią Barbaricum, co kryje się pod symbolicznym sformułowaniem „,zapuszczania włosów” na modłę barbarzyńską.

\footnotetext{
74 Ibidem, II 1 (s. 24).

75 A. E. Jones, op. cit., s. 82.

76 Jak podaje M. R. Salzman: „The traditional criteria for membership included noble birth, distinction in public service, high moral character, intellectual culture, and sufficient wealth". Dodatkowo autorka podkreśla dziedziczność tytułów. Jednocześnie wskazuje na istotną zmianę, rozwijającą się w IV wieku, kiedy to dokonuje się prawne zdefiniowanie oraz nakaz „(...) high social and economic status in one of several distinct sets of elites". Przyjmuje się, że wydanie takiej rezolucji miało na celu wykształcenie jednej, spójnej warstwy arystokracji, zrzeszającej w swych szeregach, oprócz dawnych wielkich rodów stanowiących trzon elit, także osoby uzyskujące nobilitację chociażby za swe zasługi na gruncie militarnym. Zob. M. R. Salzman, op. cit., s. 20-24.

77 D. Zołoteńki, Galia u schyłku..., s. 69.
} 


\section{Arystokracja a Barbaricum}

Cofnijmy się do wcześniejszego wieku. W myśl słów potrzeba matką wynalazków wprowadzono, począwszy od IV wieku, novum, które miało być zabezpieczeniem miejscowych elit przed barbarzyńcami. Otóż, powołano tzw. buccellarii - żołnierzy, wchodzących w skład prywatnych wojsk ${ }^{78}$. Stanowili oni dobre rozwiązanie ówczesnych problemów. Arystokracja ${ }^{79}$, w naturalny sposób dążąca do utrzymania swej pozycji i zabezpieczenia swych włości, starała się zapewnić sobie prywatnych buccellarii, ewentualnie pozyskać odpowiedniego patrona dysponującego takimi oddziałami ${ }^{80}$. Wytworzenie tego typu jednostek skutkowało pogłębieniu oderwania od władzy Rzymu, szczególnie w V wieku. Należy dodać, że za czasów Aecjusza ${ }^{81}$ upowszechniło się osadzanie grup plemiennych w Cesarstwie Zachodnim, jako gwarant i potwierdzenie sojuszy (tzw. foedera) $\mathrm{z}$ nimi zawartych, w zamian za wsparcie militarne dla Imperium ${ }^{82}$.

W sytuacji, w której arystokracja nie mogła już liczyć na znaczące wsparcie ze strony Imperium, mamy do czynienia z coraz większym rozluźnieniem więzów z Cesarstwem. Dlatego w praktyce elity coraz częściej szukały poparcia i pomocy wśród miejscowych władców barbarzyńskich. Ponadto, na porządku dziennym było rozdawnictwo ziemi dla ludności plemiennej, jako nagrody za pomoc dla armii rzymskiej, w stłumieniu buntów. Wszystko to przyczyniało się do zmniejszania ilości ziem będących do tej pory w domenie rzymskich władców, którzy tracili swoje wpływy na rzecz Barbaricum. Co więcej, wraz z upływem czasu dotychczasowi foederati przeszli także pewną zmianę. Wraz z osłabieniem wpływów Cesarstwa lokalne siły zdobywały coraz większe znaczenie; taka sama sytuacja wykształciła się wśród wojowników barbarzyńskich, którzy pełnili rolę „funkcjonariuszy imperialnych na obszarach przez siebie zajmowanych" ${ }^{83}$. W tym momencie lokalne elity miały utrzymywać pozostałości władzy cesarskiej w tych

78 Ibidem, s. 71.

79 Jeżeli chodzi o arystokrację galijską, wyróżnić możemy trzy najwybitniejsze rody: Awitusów wywodzących się z Owernii, Magnusów z Narbony (Narbonne) i Apollinarisów z okolic Vienna (Vienne) i Lugdunum (Lyon). Właśnie z tych rodów wywodzili się przedstawiciele galorzymskiej elity pełniący funkcje dostojników zarówno państwowych, jak i kościelnych, a także militarnych. Zob. ibidem, s. 72 i 86.

80 Ibidem, s. 72.

81 Dominacja Aecjusz przypadała na lata: 435-454. Zob. M. Jaczynowska i M. Pawlak, op. cit., s. $400-404$.

82 Sojusze te były zawierane m.in. z Burgundami (436-437), Wizygotami (439 rok), Frankami (447-448 rok). Oczywiście, tereny zasiedlane przez plemiona barbarzyńskie nie posiadały autonomii, w dalszym ciągu obowiązywało na nich zwierzchnictwo Imperium. Miało to swój wyraz m.in. w utrzymaniu na tych ziemiach administracji cesarskiej, zarówno wojskowej, jak i cywilnej. Zob. D. Zołoteńki, Zachód rzymski..., s. 106 i 108-109.

83 Ibidem, s. 75. 
regionach. Zadanie to nie było łatwe, zwłaszcza ze względu na rosnąca pozycję lokalnych królestw barbarzyńskich. Dodatkowych problemów, pogłębiających niekorzystną sytuację, dostarczali sami Rzymianie. Już na początku V wieku, za czasów Aecjusza, poszukiwano rozwiązania problemu wzrastających wpływów wizygockich w Akwitanii. Wyjściem z sytuacji miało być sprowadzenie innych plemion, mających stanowić przeciwwagę dla Wizygotów ${ }^{84}$. W wyniku takich działań większym poparciem zaczęli cieszyć się „panowie wojny”, jak określił ich Dawid Zołoteńki. Wspomniani warlords to m.in. sami przedstawiciele galorzymskiej arystokracji dysponujący własnym zapleczem wojskowym, którzy, przy poparciu miejscowej ludności, zastępowali dotychczasowych państwowych urzędników, przez co umacniali swą pozycję na terenach de facto im podległych ${ }^{85}$. Oczywiście, największym splendorem cieszyła się osoba piastująca urząd magister militum, czyli dzierżąca władzę militarną nad prowincją. Funkcja ta miała uznanie zarówno wśród Rzymian, jak i barbarzyńców. Należy także wspomnieć, iż od czasów Aecjusza ośrodkiem, stanowiącym „centrum dowodzenia” Galią stało się Arelate (Arles), w którym rezydował zwycięski wódz ${ }^{86}$.

Najważniejszymi urzędami spotykanymi w prowincjach były: prefekt i wikariusz. Prefekci byli wybierani, na jeden rok lub dwa lata, spośród viri clarissimi zaangażowanych w działalność polityczną i będących w dobrych kontaktach $\mathrm{z}$ arystokracją Italii ${ }^{87}$. Ponadto, ich wybór był zatwierdzany za pomocą specjalnych pism, tzw. codicilli, przez samego cesarza ${ }^{88}$. W swych rękach gromadzili władzę sądowniczą, nadzorowali pobór podatków, a także sprawowali funkcję kontrolerów aktów prawnych i legislatywy cesarskiej. Ponadto, byli oni członkami consistorium jako doradcy cesarscy oraz zasiadali w senacie rzymskim. Posiadali także uprawnienia umożliwiające zarządzenie natychmiastowych przymusowych robót w obliczu zagrożenia, np. budowę umocnień czy też fortyfikacji.

${ }^{84}$ Za rządów Aecjusza sprowadzono: Franków do prowincji Belgica, Alanów osiedlonych w okolicy Aureliani (Orléans) i Valentia (Valence), Burgundów w Saupadii (tereny leżące wokół gór Jury i Jeziora Genewskiego), oraz Sasów w Normandii i przy ujściu Loary, Alamanów w Alzacji, czy Brytów na obszarach Armoryki. Zob. ibidem, s. 76-77.

85 Wspomnieć należy, że arystokracja galijska należała do niezwykle bogatej i wpływowej grupy. Niejednokrotnie, dzięki jej poparciu, w Galii, do władzy dochodziły konkretne osoby, tak było w przypadku m.in.: Awitusa (455-456) czy Majoriana (457-461). Zob. ibidem, s. 77, 84 i J. Wiewiorowski, Odbudowa rzymskiej administracji nad dolnym Dunajem u schytku antyku - Moesia Secunda i Scytia Minor, [w:] Barbarzyńcy u bram imperium..., s. 258-259.

86 D. Zołoteńki, Galia u schyłku..., s. 77.

87 Mianem vir clarissimus określane były osoby wywodzące się z arystokracji senatorskiej. Tytuł ten był tożsamy z vir illustris odnoszącym się to osób posiadających dziedziczny status senatorski. Zob. ibidem, s. 80-81 i 86. Dodać należy, że w twórczości Sydoniusza najczęściej spotykamy następujące określenia: vir clarissimus, vir illustris oraz spectabiles. Zob. A. E. Jones, op. cit., s. 83-84.

88 D. Zołoteńki, Galia u schytku..., s. 83. 
Prefekci nadzorowali pocztę państwową, dbali o nadzór i naprawę dróg publicznych, sprawowali kontrolę nad szkołami w Galii ${ }^{89}$. Wikariusze natomiast pełnili urząd zastępcy prefektów, pomagając w niższych wagą sprawach. Wraz z biegiem czasu, i utratą coraz to większych ilości ziem na rzecz barbarzyńców, ich rola malała ${ }^{90}$. Dodatkowym argumentem przemawiającym za silnie ugruntowaną pozycją arystokracji galijskiej był fakt obsadzania urzędu prefekta. Urząd ten w przeważającej mierze obsadzany był osobami wywodzącymi się z arystokracji senatorskiej, oczywiście zdarzały się nominacje do piastowania tego stanowiska wśród ludzi pochodzących z niższych warstw, niemniej jednak były one ściśle powiązane, przez różnego rodzaju układy, patronaty czy też koligacje rodzinne, $\mathrm{Z}$ wielkimi galijskimi rodami ${ }^{\text {19}}$.

Począwszy od V wieku mamy do czynienia niejako z monopolizacją urzędów na terenie Galii, kiedy to, od czasów Honoriusza, najwyższe funkcje na terenach galijskich zaczynają pełnić przedstawiciele najważniejszych rodów galorzymskich. Miało być to spowodowane przeniesieniem rezydencji cesarskiej do Rawenny, Rzymu i Mediolanu, a więc oddaleniem władzy centralnej od Galii. Jednocześnie, taka zmiana mogła osłabiać pozycję elity galorzymskiej, niebędącej już w bezpośredniej strefie wpływów cesarzy ${ }^{92}$.

W tej sytuacji rozsądnym posunięciem zdawało się być przeniesienie stolicy Galii z Treviri (Trier) do Arelate (Arles), o którym było już wspominane. Miało to zapewnić, przez bliskość cesarskiej rezydencji w Italii, lepszy kontakt z władzą centralną93. Znaczenie miasta podkreślone zostało przez cesarza Konstantyna Wielkiego, który tu właśnie przeniósł, z Ostii, państwową mennicę ${ }^{94}$, w której bito monety z napisem CONST (antina) ${ }^{95}$. Przeniesiono tutaj także siedzibę prefektury i wikariatu, a także wzniesiono tzw. basilica Constantia oraz podniesiono Arelate do rangi metropolii Kościoła galijskiego ${ }^{96}$. Co więcej, w stolicy Galii miały odbywać się coroczne, począwszy od 418 roku, Concilium VII

\footnotetext{
89 Ibidem, s. 95-96, 98-99 i 105-106.

90 Ibidem, s. 106-109.

91 Ibidem, s. 86.

92 Ibidem, s. 84-85.

93 Nowa stolica Galii miała być odpowiedniejsza, nie tylko pod względem odległości od Rzymu, ale także pod względem militarnym. Została bowiem lokowana na wzgórzu pośród bagnistych terenów, co więcej, umiejscowienie jej na prawym brzegu Rodanu zapewniało stałą komunikację wodną, a zbudowanie portu nadawało miastu możliwość pełnienia funkcji bardzo znaczącego centrum handlowego pomiędzy bogatym południem galijskim a Italią. Zob. ibidem, s. 88.

94 Wyróżnienie ze strony cesarza pociągało za sobą liczne inwestycje i rozbudowę całego miasta. Między innymi powstały tu liczne budowle użyteczności publicznej (teatr, forum, cyrk, skarbiec, magazyny), termy oraz pałace. Zob. ibidem, s. 88-89.

95 Ibidem, s. 89.

96 Ibidem, s. 89-90.
} 
Provinciarum $^{97}$. W Arelate przebywali także cesarze; $9 / 10$ lipca 455 roku w tym mieście dokonała się proklamacja Awitusa na tron cesarski. Kolejny cesarz Majorian - przebywał w mieście ponad rok.

Nieunikniony schyłek panowania rzymskiego w Galii przyniósł kryzys wywołany obaleniem i zamordowaniem przez Rycymera, w 461 roku, cesarza Majoriana. Był to moment przełomowy, od którego nastąpiły znacznie potężniejsze niż kiedykolwiek ruchy migracyjne plemion barbarzyńskich wewnątrz Galii. Już w 469 roku możemy mówić o umbra imperii, w której skład wchodziły jedynie południowe tereny: Alpes Maritimae, Narbonensis Secunda i Viennensis ${ }^{98}$. Pozostałe ziemie, albo znajdowały się już pod kontrolą Barbaricum, albo zostały odcięte od Imperium i tym samym, w praktyce, władza prefektów już tam nie sięgała. Należy dodać, że Herwig Wolfram zaznaczył, powołując się na zapiski Sydoniusza, iż przed 476 rokiem południowa Galia była nienaruszona ${ }^{99}$. Takie twierdzenie wydaje się błędne zwłaszcza w świetle przedstawionych powyżej faktów. Ponadto, H. Wolfram sam podaje przykłady świadczące o zmianach. Król Gotów sprawował władzę wykonawczą na terenie Siedmiu Prowincji ${ }^{100}$. Ponadto, podatki $\mathrm{z}$ tych ziem były przeznaczane m.in. na utrzymanie gockich oddziałów ${ }^{101}$. W takim przypadku bardziej właściwe wydaje się mówienie o nienaruszalności w odniesieniu do kontynuacji administracji rzymskiej na tych terenach. Inne aspekty pozwalają natomiast wnioskować, iż Euryk umacniał swoją władzę na zajętych ziemiach, przejmując uprawnienia zarezerwowane dotychczas dla rzymskiej arystokracji i tym samym stając się królem Siedmiu Prowincji.

Kolejnym novum w administracji galijskiej w V wieku było stopniowe ograniczenie zasięgu władzy prefektów. Poczynając od strat terytorialnych, w wyniku których tereny pozostające pod zwierzchnictwem Cesarstwa uległy znacznemu skurczeniu, kolejnym etapem miało być zlikwidowanie urzędu prefekta Galii. Na skutek takich zmian, pod względem administracyjnym, terenom galijskim pozostały już tylko galorzymskie civitas oraz ecclesia ${ }^{102}$. W związku z tym, ko-

97 Concilium VII Provinciarum było swego rodzaju radą, w której zasiadali przedstawiciele większości miast galijskich, a także concilium pełniło funkcję reprezentanta prowincji Galii. Zob. ibidem, s. 90 i $124-125$.

98 Pozostałe tereny znajdowały się pod kontrolą królów barbarzyńskich. Wizygoci opanowali tereny południowo-zachodniej Galii aż po północną Hiszpanię, oraz stopniowo rozszerzając swe wpływy w kierunku północnym - aż po Loarę, na wschód - po Rodan, Burgundowie - Lugdunum. Zob. ibidem, s. 93-95.

99 H. Wolfram, Historia Gotów, przekł. R. Darba-Staab, I. Dębek i K. Berger, Warszawa - Gdańsk 2003, s. 243.

100 Ibidem, s. 243.

101 Ibidem, s. 243-244.

$102 \mathrm{Z}$ czasem administracja ewoluowała, stopniowo przystosowując się do nowych realiów związanych z panowaniem królestw barbarzyńskich. W toku tych przemian wykształciła się nowa forma 
lejną „siłą”, niejako zarządzającą, były biskupstwa, zgrupowane wokół głównego miasta prowincji - metropolii ${ }^{103}$. W tychże metropoliach rezydował główny patriarcha, któremu podlegała cała administracja i hierarchia kościelna prowincji ${ }^{104}$. $\mathrm{Z}$ biegiem czasu zwiększała się rola biskupów, którzy zastępowali nawet urzędników państwowych. Ponadto zyskiwali, w wyniku coraz większej ekspansji Barbaricum i ogółu konfliktów wewnętrznych, coraz większą autonomię. Sytuacja ta nie uległa zmianie mimo wzrastających wpływów królestw barbarzyńskich i, co za tym idzie, rozprzestrzeniania się arianizmu oraz pogaństwa. Królowie barbarzyńscy stopniowo przyjmowali chrześcijaństwo. Przyjmuje się, że pierwszym biskupem Gotów, na początku wieku IV, był Teofil. Schedę po nim objął Ulfila ${ }^{105}$. Rozprzestrzenianie się chrześcijaństwa wśród plemion barbarzyńskich wiązało się z wędrówką, w kierunku Cesarstwa Zachodniego, Wizygotów ${ }^{106}$. Po dotarciu m.in. na tereny galijskie, barbarzyńcy byli już zaznajomieni z nową religią. Prawdopodobnie nie były im też obce struktury hierarchii Kościoła chrześcijańskiego. Dlatego też nowi władcy niejednokrotnie godzili się na niezależną egzystencję Kościoła ${ }^{107}$, oczywiście zdarzały się nieliczne przypadki ograniczania wpływów chrześcijaństwa czy wręcz próby „wyplenienia” tej religii.

urzędu - comes civitatis, która wiązała się z mniejszymi kosztami niż utrzymanie prefektury. Komes miejski miał zarządzać terytorium galijskim, było to możliwe dzięki rozbudowanej sieci $c i$ vitates w Galii. To rozwiązanie administracyjne zostało przejęte i stosowane w późniejszym czasie - za panowania Merowingów. Zob. D. Zołoteńki, Galia u schyłku..., s. 162 i 295-299.

103 Ibidem, s. 119-120.

$104 \mathrm{~W}$ gestii metropolity było m.in. sądownictwo kościelne, zwoływanie synodów prowincjonalnych i przewodniczenie im, sprawowanie kontroli nad majątkami kościoła, udział w elekcji nowych biskupów. O wyborze jednego z biskupów pisze Sydoniusz w jednym ze swych listów. Zob. ibidem, s. 120 i Sydoniusz Apolinary, Ep. VII 9 (s. 126-130).

105 Konsekrowany przez Euzebiusza z Nikomedii Ulfila został biskupem Gotów, ponadto przypisuje się mu przekład części Pisma Świętego na język gocki oraz utworzenie szkoły dla duchownych, pełniących posługę na terenach zasiedlonych przez Gotów. Zob. R. Kosiński, Religie cesarstwa rzymskiego $w$ V stuleciu, [w:] Świat rzymski w V wieku, (red.) R. Kosiński i K. Twardowska, Kraków 2010, s. 407; M. Simon, Cywilizacja wczesnego chrześsijaństwa I-IV wiek, przekł. E. Bąkowska, Warszawa 1981, s. 395; J. Danielou i H. Marrou, Historia Kościoła. Od początków do roku 600, przekł. M. Tarnowska, Warszawa 1984, s. 222-223.

106 Po opanowaniu rzymskich terenów w Afryce schrystianizowani Wandalowie utworzyli autonomiczny Kościół ariański na czele z patriarchą. Prawdopodobnie Burgundowie przyjęli arianizm pod wpływem swego władcy Gundioka, wywodzącego się z wizygockiej arystokracji. Podobnie Swebowie, będący w orbicie oddziaływań Wandalów, przyjęli w 466 roku arianizm. Wspomnieć należy, że król Wandalów Gejzeryk był przeciwnikiem katolicyzmu, w wyniku czego na ziemiach mu podlegających mamy do czynienia z prześladowaniem Kościoła katolickiego (zamykanie kościołów, konfiskata majątków kościelnych, usuwanie i więzienie biskupów) szczególnie na terenie wcześniejszej prowincji rzymskiej - Africa Proconsularis - ,perły w koronie wizygockiej”. Dopiero od VI wieku, królestwo Wizygotów uzyskało, za sprawą króla Hilderyka (523-530), swobodę wyznania. Zob. R. Kosiński, op. cit., s. 408-410.

107 D. Zołoteńki, Galia u schyłku..., s. 122-123. 
Jednocześnie, dla administracji Galii, bardzo ważnym aspektem, na który wskazuje D. Zołoteńki, miało być istnienie senatu galijskiego, oczywiście nie tak licznego jak senat Rzymu, jednakowoż w jego skład mieli wchodzić przedstawiciele arystokracji galijskiej. Co więcej, na istotną rolę tego zgromadzenia wskazywałyby ich poczynania po ataku na Rzym Wandalów, kiedy to Galia, dotknięta paraliżem administracyjnym spowodowanym niemocą ze strony centralnych władz, była zmuszona decydować sama o sobie ${ }^{108}$. Na zgromadzeniu w Ugernum, 9 lipca 455 roku, doszło także do aklamacji wspominanego wcześniej cesarza Awitusa. Od tego momentu możemy mówić o zmianie dotychczasowego kierunku polityki rzymskiej w relacjach z Barbaricum. Jak podaje sam Sydoniusz, najwyraźniej uczestniczący w tych wydarzeniach jako członek arystokracji galorzymskiej, iż sam Teodoryk II ${ }^{109}$, władca Wizygotów, wraz ze swoją świtą brał udział w powołaniu na tron cesarski nowego władcy Zachodu ${ }^{110}$. Tego typu spotkanie, przy jednoczesnym wsparciu wizygockiej armii i potwierdzeniu ich roli jako oddanych foedus, mogło zostać odczytane jako wyraz wzajemnej współpracy obydwu stron. Jednocześnie należy wspomnieć, iż arystokracja Italii nieprzychylnie odnosiła się do takiego obrotu spraw, upatrując w nich próbę osłabienie swojej pozycji oraz wyniesienie na tron osoby spoza ich kręgu ${ }^{111}$. Co więcej, elity galijskie same decydowały o tym, komu udzielą poparcia. Tak było w przypadku uznania Majoriana i Rycymera, kiedy to północna Galia odmówiła swego poparcia, woląc oddać się w ręce Burgundów ${ }^{112}$ oraz w przypadku usunięcia z urzędu prefekta Galii - Arwanda.

Przedstawione poczynania niewątpliwie mogą świadczyć o rosnącej niezależności galorzymskiej arystokracji. Późniejsze zdarzenia, jak choćby wojna domowa w Italii, także mogły być uważane za możliwość poszerzenia swych wpływów wśród miejscowych elit. Jednak mogłoby wydawać się to dość dużym uproszczeniem. Bynajmniej nie można odrzucać wielkiego przywiązania, jakim arystokracja galorzymska darzyła Imperium. Być może właśnie tak silna pozycja elit świadczyć mogła o poszanowaniu dla tradycji, praw i całego dorobku Cesarstwa. A zatem wszelkie posunięcia mające zagwarantować trwałą pozycję arystokracji mogłyby być przejawem ich więzi z Rzymem. Sam Sydoniusz podkreślał swoje przywiązanie do kultury łacińskiej i starannego wykształcenia oraz poszanowania praw i przywiązania do godności obywatela Imperium.

\footnotetext{
108 Ibidem, s. 130-131. O wspominanym trybunale galijskim wzmiankuje Sydoniusz. Zob. Sydoniusz Apolinary, op. cit., I 1 (carm. VII).

109 Teodoryk II jawi się tutaj jako przyjaciel i oddany sojusznik Rzymu, jednak na coraz szerszą skalę próbował on poszerzyć swoją władzę. Między innymi zdymisjonował, obwołanego z woli cesarza naczelnikiem wojsk w Hiszpanii, Nepocjana. Zob. D. Zołoteńki, Galia u schyłku..., s. 204. 110 Ibidem, s. 132-133 i Sydoniusz Apolinary, op. cit., I 3 (carm. VII).

111 D. Zołoteńki, Galia u schytku..., s. 128-129 i 133

112 Ibidem, s. 143.
} 


\section{Zakończenie}

Allen E. Jones zaproponował następujący podział społeczeństwa galijskiego, według statusu społecznego ludności: arystokracja, dobrze sytuowani wolni ludzie (ingenui), wyzwoleńcy (pauperes) oraz niewolnicy ${ }^{113}$. Jak widzimy, zawsze na pierwszym miejscu widnieje, niezależnie od państwa czy prowincji, arystokracja. Zgodnie z tymi prawidłowościami elity rzymskie znajdowały się na szczycie drabiny społecznej do przełomowego V wieku. Wówczas znika z mapy Cesarstwo Zachodnie, znika terytorialna przynależność do Imperium. Społeczeństwo staje przed wyborem: poddać się czy walczyć? Zaakceptować czy odrzucić zmiany? $\mathrm{W}$ przeważającej mierze miejscowe elity wybierają pierwsze rozwiązanie - zaakceptowanie nowej rzeczywistości. Następuje transformacja, swego rodzaju przejście od obywateli Imperium do nowych państwowości spojonych za pomocą trzech elementów: Romanitas, Germanitas i Christianitas. „Nowa arystokracja” zaczyna formować się wokół nich. Dzięki swojemu prestiżowi, wykształceniu, doświadczeniu w sprawowaniu urzędów - elity łatwiej przystosowują się, stając się podstawą kształtującej się administracji królestw barbarzyńskich. Od początkowej niechęci, widocznej w twórczości Sydoniusza Apollinarisa, następuje stopniowa zmiana w relacjach z Barbaricum.

Na zakończenie wypada stwierdzić, że transformacja arystokracji rzymskiej następowała stopniowo, a dzięki polityce barbarzyńskich władców wykazujących życzliwość dla tej grupy społecznej możliwe było „wchłonięcie” nobilów stających się elitą nowego świata.

\section{Transformation of Roman aristocracy in the Gaul territory in the $\mathbf{V}$ century}

The article aims to present transformation of Roman aristocracy in the Gaul territory in the V century. Analyzing rich legacy of Sydoniusz Apollinaris, who represented Gaul-Roman elites, we can recreate the picture of Gaul of his days - shown against the background of transformations taking place in the Roman Empire.

The V century seems to be critical in the history of Gaul, as it was then that various barbaric tribes, wading through the defense line on the Rhine, "flooded" the Gaul territory. Simultaneously numerous usurpations of imperial power occurred in the West, causing weakening of Roman influence in the dependent provinces. In this situation, Roman aristocracy, playing until that moment a key role in preservation of traditional Roman administration and of Church organizations

113 A. E. Jones, op. cit., s. 76. 
- deeply rooted in the territories belonging to the Empire, and thus guaranteeing the continuity of the imperial authority - was bound to answer a difficult question: what to do, when the territorial dependency disappears together with the disappearance of the Western Empire?

That is why in the West a certain transformation was to occur; a new order, based on three interconnected elements; Romanitas, Germanitas i Christianitas, was to be created.

Key words: Gaul, Roman aristocracy, Sydoniusz Apolinaris, Christianity, barbarians

\section{Bibliografia}

\section{Źródła}

Cicero, Rozmowy tuskulańskie, przekł. J. Śmigaj, Warszawa 2010.

Sydoniusz Apolinary, Listy $i$ wiersze, przełożył, opracował i wstępami poprzedził M. Brożek, Kraków 2004.

\section{Literatura}

Danielou J., Marrou H., Historia Kościoła. Od poczq̨tków do roku 600, przekł. M. Tarnowska, Warszawa 1984.

Jaczynowska M., Pawlak M., Starożytny Rzym, Warszawa 2008.

Jones A. E., Social mobility in late antique Gaul. Strategies and opportunities for the non-elite, Cambridge 2009.

Kosiński R., Religie cesarstwa rzymskiego $w$ V stuleciu, [w:] Świat rzymski $w$ V wieku, (red.) R. Kosiński, K. Twardowska, Kraków 2010.

Pawlak M., Konflikty Rzymian z barbarzyńcami nad Renem w latach 365-425, [w:] Barbarzyńcy u bram imperium, (red.) S. Turlej, Kraków 2007.

Salzman M. R., The Making of a Christian Aristocracy. Social and religious change in the Western Roman Empire, Harvard 2004.

Simon M., Cywilizacja wczesnego chrześcijaństwa I-IV wiek, przekł. E. Bąkowska, Warszawa 1981.

Styka J., Sydoniusz Apollinaris i kultura literacka, Kraków 2008.

Szabat E., Edukacja i kultura w V wieku, [w:] Świat rzymski w V wieku, (red.) R. Kosiński, K. Twardowska, Kraków 2010.

Wiewiorowski J., Odbudowa rzymskiej administracji nad dolnym Dunajem u schytku antyku - Moesia Secunda i Scytia Minor, [w:] Barbarzyńcy u bram imperium, (red.) S. Turlej, Kraków 2007.

Wolfram H., Historia Gotów, przekł. R. Darba-Staab, I. Dębek i K. Berger, Warszawa Gdańsk 2003. 
Zołoteńki D., Galia u schyłku panowania rzymskiego, Kraków 2011.

Zołoteńki D., Zachód rzymski w latach 425-476, [w:] Barbarzyńcy u bram imperium, (red.) S. Turlej, Kraków 2007. 